\title{
The Form and Meaning of The Mekongga Custom Marriage Ritual in South East of Sulawesi
}

\author{
Wa Ode Sitti Hafsah \\ \{waodesittihafsah@uho.ac.id\} \\ Halu Oleo University Kendari, Sulawesi Tenggara, Indonesia
}

\begin{abstract}
This article discusses the form and the meaning marriage ritual in the Mekongga custom in Kolaka Regency, South East of Sulawesi. The data was collected through observation, interview, and documentation. The discussion uses semiotic theory with qualitative research design, and uses three stages of data analysis, namely data reduction, presentation, and makes conclusions. The marriage ritual in Mekongga custom consists of several stages, namely mesuko-suko or menduutudu (pre propose), tebua (propose), mokondetoro (engagement), mombekaako (bring the wedding fees), and perapua stages (wedding party). Each stage has a lot of meaning, such as the meaning of openness, prudence, consistency, and courtesy. The implementation of these rituals make the intensive interaction and communication among of the family members widely. In addition, rituals like this can bring back the kinship relationship that are broke or have been far apart. This kind of ritual has a very broad function, beside of has a function as balancer in social institution it also functioning to convey the message of the ancestors in order to create a conducive situation of the society. In short, marriage ritual in Mekongga custom has several forms which is preceded by preproposed and ended by wedding party, and each form or stage has certain meaning.
\end{abstract}

Keywords-Form, meaning, mekongga, marriage ritual

\section{Introduction}

The cultural diversity that possessed by every region in Indonesia is a source of knowledge as a form of civilization in various aspects of life. The Local culture as a source of knowledge is important because it involves life and the life of the owner of the community, such as local wisdom, value system, traditional knowledge (local knowledge), history, law, custom, medicine, system of knowledge and religion, astrology, and the various of art products. The nation's cultural heritage is a reflection of the height of the nation's civilization. And one of the characteristics of a large and advanced nation is a nation that is able to respect and preserve their ancestral cultural heritage. The more the cultural heritage of the past that can be explored and preserved, then the cultural heritage should be increasingly appreciated.

Based on the complexity of local cultural content, so the study of local culture, especially on form aspect and its meaning is very important, because beside of to being a vehicle for understanding the nation identity also as a vehicle in the process of cultural inheritance between 
generation. The meanings of ritual culture are very instrumental in various of life management. The meaning or values that contained in that culture can give a positive influence to the life of the society. If the meaning and values of that culture are integrated into each individual so it can create harmonious, comfortable, and prosperous life. In fact, the regional development through of the social culture integration aspect is very important because the region and society cannot be separated from culture aspect.

Based on the description above, concerning the importance aspect of culture, then the discussion of form and meaning in one of South East Sulawesi culture is necessary. This article will concern on discussion of form and meaning of Mekongga wedding ritual in South East Sulawesi. The Mekongga wedding ritual has its own unique and full of meaning. So the description of its ritual is worth to be known by public. In addition the discussion concern on the form and the meaning of Mekongga wedding party in Kolaka Regency, South East Sulawesi, Indonesia.

To discuss the object of this study, it uses semiotic theory.Semiotic is one of the sciences or analyze method for sign teaching. The signs are vice that we use in efforts trying to seek the way in this world, in the middle of the human and human together. Charles Sanders Pierce statesthe sign as one of the grip someone the consequence from interesting with the conception or the capacity. The signs itself can be defined as one of the base social convention that awaken before, can be reputing represent one of the each other. Barthes [1] statesthat semiotic is theory that can explain the production and interpretation meaning. The base principle is the meaning made by advance of the act and the object that be function as the sign in relation with other sign. Each sign can be interpreting in 3 types, such as the focus of general indication realization, the focus of the object/referent, and the focus of interpretation.

Basically, semiotic theory is improved by many experts with the background thinking and disciplinary in difference. Semiotic is the study about the sign and how the sign is working in human life [2]. Saussure [3] says that semiotic is the study ofthe sign as part from social life. Semiotic theory can be organized in twoparts, namely structural semiotic (set of structuralism de Saussure) and pragmatic semiotic. In semiotic context, Geertz [4] offers the way to interpret the cultural with the way to present of configuration or the system of symbols meaning in becoming deep and comprehensive. Semioticlookat the cultural as sign system. Human as member of the society that being inside of cultural social, give a meaning to sign appropriate with the valid convention.

Basically, there are several previous studies which are relevant to this study. Tarimana [5] discussed the culture of Tolaki including marriage rituals. In his study, Mekongga is viewed as Tolaki ethnic, so the data came from both Konawe and Kolaka societies as Tolaki ethnic. Azis [6] studied about the role of kalosara culture in building characters of Tolaki people. Azis did not explain the form and meaning of marriage rituals in Kolaka/Mekongga ethnic. Su'ud [7] investigated the law of Tolaki custom but did not describe particularly the form and meaning of marriage rituals in Kolaka/Mekongga ethnic. Su'ud [8] also studied about compilation of marriage custom law in Southeast Sulawesi (Tolaki, Buton, Muna, Morenene, and BugisMakassar). Although his study described the marriage ritual of Mekongga/Tolaki ethnic, but it did not explore more about form and meaning of the ritual. Syamsumarlin, et.al. [9] studied about development and building of culture values as inheritance of local richment in Kolaka regency. Their study explained all cultures, mainly life cycles of Mekongga ethnic, which include birth, marriage, and death rituals.

Based on the explanation and previous studies above, it has not been found study of form and meaning particularly of marriage rituals in Mekongga ethnic. This study thus investigated the form and the meaning marriage ritual in the Mekongga custom in Kolaka Regency, South East of Sulawesi. The form refers to the stages of marriage rituals. Meaning here is not only related to the merely meaning but also meaning which arouse certain function. 


\section{Method}

This study uses qualitative approach. The data was collected from informant that choose in purposive, such as the characters of the Mekongga society in Kolaka, government area that be related in regency, sub district until village officials, and ethnic local society of Mekongga. In addition the technique for taking the data that used in this studyare observation, interview, and documentation. The technique of data analysis that used in this study refers to Miles and Huberman [10] that data analysis activity of qualitative studyconsist of three lines activity that happen in coincide such as reduction, data display, and conclusion. In reduction, it chose main things from all of data that available from some various sources. In data display, it presented the data that have been reduced based on its characteristic. In this stage, it is done analysis of data, either from interview, observation, or documentation. In conclusion, it gave accumulation from the first conclusion is directed for answering whole problems in this study.

\section{Result and Disscussion}

\subsection{The Forms of Marriage Ritual From Mekongga Custom}

The marriage in Mekongga costum is called perapua or pepakawai. The merapu term or perapua has a meaning that brunched including husband, wife, children, parent in law, uncle, aunt, sister/brother in law, cousin, grandfather, grandmother, and grandchild like a tree has thick and leafy (Tarimana, 1984). Pepakawai is the ceremony that unifiesa man and woman in a holy union for finding and building a household of life. According to Mekongga society, a marriage is one of the thing that scared and holies and the success in found it and defending the family and so surely that is the responsibility of husband-wife moral.The marriage rituals according to Mekongga's custom consists of several basic steps, they are:

1. Mesuko-suko or Menduutudu (Praproposal)

In this step, if someone wants to marry off their son, usually the male parents will send their trusted representative to come to the girl's house with the intention of asking some question or asking about the girl conditions. They asked if the girl is free, there is no one to tie her up and is there is a way to propose their girl. That male representative usually brings enough money, cigarette, and matches that wrapped in white clean fabric, and also one piece of sarong. That white cleanfabric symbolizes the sanctity of men's intentions and arrival. In this step, the man side and the woman side are crossed with sweet words, modesty, and meaningful.

After the man's representative said their intention, usually the woman's parents will call their daughter and asking about the intention of the man's representative. If the women is agree, so that the man's representative will go home and inform to man's parents to continue to the third steps. The female parents will discussed it first with their daughter and her brothers. A few days later the information will be given with two kinds of reply, they are: (1) the equipment's that brought by the male side is returned accompanied by an additional non-perforated coin, this is means that he women does not agree or has no way, (2) the equipment that brought by the male is not returned, but it's returned with a perforated coin, ring, or rattan that made like a ring, this is means that the woman agrees or has a way.

2. Tebua Step (Proposal)

Tebua is the proposal steps and also give the engagement costs. After there is an opportunity between both of the family, so the male side will ask for a Tolea's service or a spokesman tradition as a connector to the woman side for asking the certain time to do an engagement. Moreover, the man side contact and invite the spokesman tradition to prepare for making a proposal and ask about what is the custom equipment that the woman side need to be 
prepared by the man side. Furthermore, the man side entrust their envoy to discuss about the certain time for the man side come for proposing marriage. After the man side pay cost for engagement and approve the engagement time, so they will take a leave. In this step, generally the main side brings a cigarette and a lighter, wrapped by a white fabric and layered by a plate as a media for delivering an order, and pay the cost for engagement as well.

3. Mokondetoro Step (Propose Marriage)

According to Mekongga wedding ritual, at the engagement time, their relatives and family are joining the event. Based on the ancestor's tenet, the engagement time must be crowded and known by their relatives. When their relatives don't know about that engagement event, so they cannot coming up at the wedding time. The man side will prepare all of the cost for engagement and the cost must increase or given to the woman side at least 2 days before the engagement. After all of the both family, the custom equipment and all of the guests have attended, so the engagement will begin.

In this stage, the man side usually brings a pack of betel nut (kumbawua) engagement sign and unite the both side. The betel nut pack consists of (1) Stem and midrib of palm as a symbol of the future bridegroom house for doing their household;(2) Wua (betel nut) as a symbol for the groom, and the branch as a symbol of the groom side; (3) Tawa bite (betel nut leaves) as a symbol of the bride, the branch and root as a symbol of bride side;and (4) Koloro (Rope), use for tying the steam and midrib palm. On engagement ritual, the groom and bride spokesman talk and respond to each other about the engagement

Basically, engagement according to the Mekongga ritual roled up by a couple of Tolea. Both Tolea sit with the legs crossed $\mathrm{u}$ and face to face with use five envelopes along the engagement process. The first Tolea represent the groom side, and the second Tolea as a bride represent. They speak alternately with five steps. First, Tolea (I) puts lopa-lopa in the right side of Tolea (II), and then puts kalosara in the right side of lopa-lopaand ask for permit to local government (Head of village and Subdistrict). After that, Tolea (I) outs envelope 1 in the right side kalosara and answered by Tolea (II). Second, Tolea (I) puts envelope 2 and again answered by Tolea (II). Third, Tolea (I) puts envelope 3 and hand over the requirements stuffs and answered again by Tolea (II). Fourth, Tolea (I) puts envelope 4, and then answered by Tolea II. Last, Tolea (I) puts envelope 5 and asking for permission to the local government.

If the submission of 5 envelopes has been done, then entire ceremony of engagement have been completed. Entire guests then wiped out all of the foods together. After that, they return to their own home. In that engagement ritual has been determined when the weeding fees increased will be submitted. Discussion of incretion of wedding fees usually has been done in one week period of time before the reception with intention to give freedom to woman side to try the best.

4. Steps of Mombekaako (Carrying the Wedding Fees)

After mokondetoro steps done, next is bringing the wedding of fees according to the agreement and the conclusion which is made at the engaged steps or process. In this steps, the man side goes to the places which is called pombokoopuaosara (custom settlement) and the wedding begins with custom settlement process which is marked with custom submission, that is puusara, customary figure, toloasara sixteen sheet of sarong, raneranembaa (parenting custom 2 sheet of sarong), and osomba (dowry). In the same night, both the bridegroom and the bride will be given jewelry by an expert to hold the way of wedding tomorrow.

5. Wedding Process

Perapua is the procession of the wedding ceremony and held at the bride's house. Before that, the ceremony is preceded by the delivery of all fare party or the cost of the marriage of the groom to the bride. In other words, before the marriage, the dowry and rene-ranembaaha should have been given to the bride. According to Mekongga tradition, the wedding ritual is divided into two types, specifically for nobility (anakia) and marriage for the general public. 
For the nobility, special aisle (walasigi) is made and the bridal welcomed by the custom recipient with the traditional dances (mondotambe, mondiriosomba, umoara, and basalonde).

Covenant of marriage begin after the delegation from the groom asking the bride's father, has he allowed her daughter to be married by the groom. After the bride's father allow it, so the next is the future bride answer the question has she allow it too. After he answers it, so the bride will sign the marriage license, and also her father signs it as a witness.

After the bride and her father sign it, so the ijabkabul (agreement answer ritual) will begin. The bride's father or the guardian that the bride's father has chosen has the right to wed the both bride and groom. Beside wed the both bride and groom, department of religious affairs also has an obligation to write the marriage document equipment. The wedding will begin by ijabkabul. After that, the representative of sub district department of religious affairs says the marriage words.

\subsection{The Meaning of Marriage Ritual in Mekongga's Custom}

Mekongga people consider the wedding as a symbol to continue the descent, to combine the genealogies, and the social position. Other side, the wedding of Mekongga tradition is a media to fixing the fissure kinship relation. The ritualistic meaning of marriage to the Mekongga ethnic that is carried out intact by the Mekongga ethnic group includes (1) the meaning of seriousness and attention, (2) openness, (3) consistency, and (4) courtesy. The four meanings are analyzed as follows.

1. Meaning of Seriousness and Attention

Marriage rituals in the Mekongga tradition contain the meaning of mindfulness, seriousness, and fullattention. This is seen in the custom of Sara Mesukosuko. Before marriage, a man must know the condition of the womanwho he will marry including the condition of her family. This stage is also conducted to find out whether the woman has been invited orproposedby someone else or not.

2. Meaning of Openness

Marriage rituals in the Mekongga tradition mean openness. This can be seen in the saratebua customs, which is an openengagement event. One of the lessons is to give an opportunity to other interested parties if there is an objection. This nature of openness is reflected in every social activity of the Mekongga community. Openness can be seen from the attitude that accepts when there are other cultures that enter the life of the Mekongga community. The Mekongga community does not close itself from any changes in times and cultures. The Mekongga community is present and mingles in cultural acculturation with other cultures as part of the process of self-development in establishing relationships with other people.

3. Meaning of Determination and Roundness (Consistency)

Marriage rituals in the Mekongga tradition contain consistency. This can be seen from the application of the Tebua custom. If the customsprocess is over, according to the Mekongga custom there is no way to cancel the marriage plan. If one party cancels, then it is a form of violation of customary law and will get customary sanctions. Mekongga people are also known as people who are consistent in everything. The determination of the Mekongga people will be maintained in the fight against injustice. This consistency of Mekongga people makes it strong and personal character that is strong in changes and cultural friction.

4. Meaning of Courtesy

All marriage rituals in the Mekongga custom contain polite orcourtesymeanings, especially to the bride's parents. In addition, the Mekongga traditional ritual also teaches respect for indigenous elders and the government. This can be seen in the stages of customary requests that always ask permission from the government before proceeding to the next stage. The 
Mekongga people believe that every generation or Mekongga people must instill themselves in the manner of courtesy.

\section{Conclusion}

Mekongga custom has some of the lifecycle rituals, especially those related to marriage. Marriageprocess in Mekongga customs consist of stages of mesuko-suko or menduutu (application/pra proposal), stages of preparation stages of mokondetoro (proposal submitted), stages of mombekaako (carrying wedding fees), and stages of perapua (event/wedding party). In the procurement process there is a stage called the mbokondetoro or mondongoniwule customary procession, which consists of: (1) the stage of application for permission for Toleano fishnet; (2) saramomberahi customary stage; (3) the customary stage of saramombepeendehi; (4) the mbokondetoro customary stage, namely the customary procession of solicitation; and (5) stages of mondutuosara customs. Basically, every ritual in the traditional Mekongga marriage contains many meanings.

\section{References}

[1] R. Barthes, Elements of Semiology (trans. Annette Lavers \& Colin Smith). London: Jonathan Cape, 1967.

[2] B. H. Hoed, Semiotik dan Dinamika Sosial Budaya. Jakarta: Faculty of Cultural Studies, Universitas Indoensia, 2008

[3] F. de L. G. (translation in I. by R. H. and H. K. de Saussure, Cours de Linguistique Generale. Paris: Arbre d'Or, 2005.

[4] C. Geertz, Tafsir Kebudayaan. Yogyakarta: Kanisius, 1992.

[5] A. Tarimana, Kebudayaan Tolaki. Jakarta: Balai Pustaka, 1993.

[6] A. Tondrang, "Peranan Kalosara dalam Pembentukan Karakter Masyarakat Tolaki," in Custom Meeting I of Tolaki ethnic, Konawe, Southeast Sulawesi, 2000.

[7] M. Su'ud, Hukum Adat Tolaki, Osara. Kolaka: Pengadilan Negeri Lembaga Pengembangan dan Pengkajian Sejarah dan Kebudayaan Tolaki, 2006.

[8] M. Su'ud, Kompilasi Hukum Adat Perkawinan di Sulawesi Tenggara (Tolaki, Buton, Muna, Moronene, dan Bugis-Makassar). Scotchom, 2011.

[9] Syamsumarlin, W. O. S. Hafsah, M. Taembo, N. Suryati, and A. Keke, "Kajian Pelestarian dan Pengembangan Nilai-Nilai Budaya sebagai Warisan Kekayaan Daerah di Kabupaten Kolaka". (2018).," 2018.

[10] M. B. Miles and A. M. Huberman, Analisis Data Kualitatif. Jakarta: Universitas Indonesia Press, 2009. 